\title{
EFFECT OF HEAT TREATMENT ON RHEOLOGICAL PROPERTIES OF MIXED NECTARS BASED ON CASHEW APPLE, MANGO AND ACEROLA PULPS
}

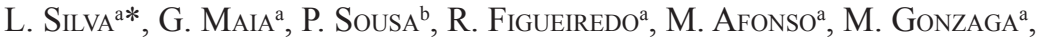 \\ C. GOMES ${ }^{\mathrm{c}}$ and E. Figueiredo ${ }^{\mathrm{a}}$ \\ ${ }^{a}$ Department of Food Science and Technology and ${ }^{b}$ Department of Gastronomy Federal University of Ceara \\ Av. Mister Hull, 2977, Campus Universitário do Pici, bl. 858, Fortaleza, Ceara, 60356-000. Brazil \\ ${ }^{c}$ Biological and Agricultural Engeneering Department, Texas A\&M University 201 Scoates Hall, 2117 TAMU, \\ College Station, TX 77843. USA
}

(Received: 10 October 2011; accepted: 25 February 2013)

\begin{abstract}
The purpose of this experiment was to evaluate the effect of heat treatment on the rheological properties of mixed nectars, based on cashew apple, mango, and acerola pulps. Ten different formulations with different mass fractions of cashew apple, mango, and acerola pulps were prepared using a simplex centroid design [with a total of $35 \%(\mathrm{w} / \mathrm{w})$ pulp] and submitted to heat treatment at $90{ }^{\circ} \mathrm{C}$ for $1 \mathrm{~min}$. Samples were collected before and after heat treatment and characterization of their rheological properties was carried out. The rheological behaviour was obtained at $25^{\circ} \mathrm{C}$, with shear rate ranging from 108 to $500 \mathrm{~s}^{-1}$ (upward curve) and from 500 to $108 \mathrm{~s}^{-1}$ (downward curve) for $1 \mathrm{~min}$ with 25 readings for each curve. The Ostwald de Waele model showed to be a good fit for all formulations studied, which showed a non-Newtonian behaviour and a pseudoplastic character. Results of apparent viscosity for the non-heated formulations were well fitted by the linear model and the heat treated formulations by the cubic model. The heat treated formulations had higher $(\mathrm{P}<0.05)$ values of consistency index and apparent viscosity, as well as lower $(\mathrm{P}<0.05)$ values of flow behaviour index compared to non-heated formulations. The rheological characterization of these formulations is a very useful tool during product development and processing control of mixed nectars of fruit juice.
\end{abstract}

Keywords: tropical fruits, beverage, heat treatment, rheology

Consumption of fruit juices is important for human health, since they are considered a major source of nutrients, and contain various phytochemicals, which reduce the risk of various diseases (CASWELL, 2009). Consumers have also become increasingly aware of the health benefits of these products, as good sources of antioxidants, such as polyphenols, vitamin $\mathrm{C}$, vitamin E, Maillard reaction products, $\beta$-carotene, and lycopene (RAMADAN-HASSANIEN, 2008).

Mixed fruit nectars are excellent options for tropical fruit juices consumption, not only do they introduce practical and distinct sensory characteristics, such as flavour and consistency, to fulfil consumers' needs; but also more competition and an exclusive niche of products to fulfil the industry's needs. The mixture of different juices can be made to combine ingredients, flavours, and aromas of different fruits, thus, increasing the acceptability and the nutritional value of these juices (Lima et al., 2008). Mixed nectars of cashew apple, mango, and acerola present a large variety of functional compounds.

Acerola (Malpighia emarginata D.C.) is a well-known tropical fruit mainly for its high vitamin $\mathrm{C}$ content (FreITAS et al., 2006) and also an excellent source of polyphenols, which

\footnotetext{
* To whom correspondence should be addressed Phone: +55 (85) 33669738; e-mail: larissamrs@yahoo.com.br
} 
provide a high antioxidant activity (MeZAdri et al., 2008; Hoffmann-Ribani et al., 2009). Mango fruit (Mangifera indica L.) is a good source of carbohydrates, minerals, organic acids, and vitamins (Bon et al., 2010) and also of antioxidants (RIBEIRo et al., 2007). Cashew apple (Anacardium occidentale L.) is also of nutritional interest, due to its high content if vitamin C (ANDRADE et al., 2008), B vitamins, minerals, carotenoids (ZEPKA \& MERCADANTE, 2009), and phenolic compounds (HoffMANN-Ribani et al., 2009), which make it one of the most important tropical fruit in Brazil used in juice production (Melo et al., 2008).

Throughout development and optimization of food products and processes, it is of fundamental importance to analyse the properties of all the materials used in order to preserve the characteristics of the final product even when the materials are submitted to different processing conditions, thus ensuring the nutritional and sensory quality of the final product and commercial viability for the industry. The study of rheological behaviour, for instance, is important because it assists in determining processing conditions allowing better control over the products and processes, with benefits to the producers, the consumers and the industry (RAMOS \& IBARZ, 1998; VASQUES, 2003). More specifically, the rheological characterization of juices and fruit pulps is of interest, since their rheological behaviour affects the formulation and processing conditions and ultimately, the acceptance of the product by consumers.

Rheological behaviour characterization in food products is done by using different mathematical models that correlates shear stress (force received by the food during processing) and shear rate (deformation originated from the applied force). According to FerReIRA and AvACA (2008), fruit and vegetable products are considered fluids of non-Newtonian behaviour, following the model of Ostwald de Waele, which is widely used to describe the rheological behaviour of foods: $\tau=\mathrm{K}(\dot{\gamma})^{n}$; where $\tau=$ shear stress $(\mathrm{Pa}), \dot{\gamma}=$ shear rate $\left(\mathrm{s}^{-1}\right), \mathrm{K}=$ consistency index $\left(\mathrm{Pa} . \mathrm{s}^{\mathrm{n}}\right), \mathrm{n}=$ flow behaviour index.

Studies about the effect of heat treatment on the rheological characteristics of mixed tropical fruit nectars are still scarce. The purpose of this study is to investigate the influence of heat treatment (pasteurization) on the rheological properties of mixed nectars containing cashew apple, mango, and acerola pulps, as a suitable alternative to tropical fruit juice processing.

\section{Materials and methods}

Pasteurized and frozen cashew apple, mango, and acerola pulps, produced by a local firm of tropical fruit juices in Pacajus, Ceará, Brazil were used in this study. Ten formulations were prepared with varying concentrations ( $\%$ weight) of cashew apple, mango, and acerola pulps based on a simplex centroid design, with a total of $35 \%(\mathrm{w} / \mathrm{w})$ of pulp for all formulations (Table 1). The concentration of total soluble solids was fixed at $11{ }^{\circ}$ Brix based on mass balance. After mixing, each formulation was divided into two parts, one was submitted to heat treatment at $90{ }^{\circ} \mathrm{C}$ for $1 \mathrm{~min}$ (pasteurization) followed by hot filling into polyethylene bottles of $100 \mathrm{ml}$, the other without heat treatment (unpasteurized) was cold filled using the same bottles. The formulations were kept frozen $\left(-18^{\circ} \mathrm{C}\right)$ until the time of analysis.

The measured rheological parameters were used as pseudo components for the adjustment of response values using linear, quadratic, and cubic models. The statistical significance of the data was determined by analysis of variance (ANOVA) at 5\% confidence level, using the software Statistica version 7.0. 
Table 1. Formulations of the mixed nectars based on cashew apple, mango, and acerola pulps

\begin{tabular}{lcccccccc}
\hline \multirow{2}{*}{ Formulation } & \multicolumn{3}{c}{ Pseudocomponents (\%) } & & \multicolumn{3}{c}{ Original components (\%) } \\
\cline { 2 - 3 } \cline { 6 - 8 } \cline { 6 - 8 } & Cashew apple & Mango & Acerola & & Cashew apple & Mango & Acerola \\
\hline 1 & 90 & 5 & 5 & & 31.5 & 1.8 & 1.8 \\
2 & 5 & 90 & 5 & & 1.8 & 31.5 & 1.8 \\
3 & 5 & 5 & 90 & & 1.8 & 1.8 & 31.5 \\
4 & 47.5 & 47.5 & 5 & & 16.6 & 16.6 & 1.8 \\
5 & 47.5 & 5 & 47.5 & & 16.6 & 1.8 & 16.6 \\
6 & 5 & 47.5 & 47.5 & & 1.8 & 16.6 & 16.6 \\
7 & 33.3 & 33.3 & 33.3 & & 11.7 & 11.7 & 11.7 \\
8 & 61.67 & 19.17 & 19.17 & & 21.6 & 6.7 & 6.7 \\
9 & 19.17 & 61.67 & 19.17 & & 6.7 & 21.6 & 6.7 \\
10 & 19.17 & 19.17 & 61.67 & & 6.7 & 6.7 & 21.6 \\
\hline
\end{tabular}

All nectars were initially homogenized at 10000 r.p.m. for one min (Omni homogenizer, USA) to decrease the particle size present in the nectar, especially for cashew apple pulp, which had a high fibre content. The rheological behaviour of nectars of cashew apple, mango, and acerola was determined using a concentric cylinder rheometer (Brookfield Searle, model R/S SST Plus 2000, Brookfield Co., USA). Determinations were carried out at $25^{\circ} \mathrm{C}$ provided by a thermostatic bath (Brookfield, model TC-502) connected to the equipment. Results of shear stress and shear rate were recorded using RHEO V2.8 software (Brookfield Co., USA). The rheological behaviour was measured with a shear rate ranging from 108 to $500 \mathrm{~s}^{-1}$ (upward curve) and from 500 to $108 \mathrm{~s}^{-1}$ (downward curve) for 1 min with 25 readings for each curve. Readings were carried out in triplicate and for each measurement a new sample was used. The Ostwald de Waele model was used to characterize the rheological behaviour of mixed fruit nectar due to its simplicity and good fit. The experimental results were fitted to the Ostwald de Waele model using SAS Software version 9.1.

The apparent viscosity values for the mixed nectars of cashew apple, mango, and acerola were obtained by the calculation of apparent viscosity using the Ostwald de Waele model, for shear rate equal to $100 \mathrm{~s}^{-1}$, which represents the shear rate of fluids being pumped through industrial pipes: $\eta_{\mathrm{a}}=\mathrm{K}(\dot{\gamma})^{n-1}$; where $\eta_{\mathrm{a}}=$ apparent viscosity $\left(\right.$ Pa.s); $\dot{\gamma}=$ shear rate $\left(\mathrm{s}^{-1}\right)$; $\mathrm{K}=$ consistency index $\left(\mathrm{Pa} \cdot \mathrm{s}^{\mathrm{n}}\right) ; \mathrm{n}=$ flow behaviour index.

\section{Results and discussions}

The Ostwald de Waele model fitted all the formulations (except 4, 7, and 8) with correlation coefficients $\left(\mathrm{R}^{2}\right)$ close to unity and mean square error (MSE) close to zero, indicating a good fit (Table 2). The flow behaviour index (n) of a fluid is used to classify its fluid flow and consequently to predict its behaviour during industrial processing under different unit operations. All samples showed a flow behaviour index (n) below one, indicating a pseudoplastic behaviour. Consequently, it was observed that an increase in shear stress resulted $(\mathrm{P}<0.05)$ in a decrease in viscosity for all formulations. 
Table 2. Parameters of the Ostwald-de-Waele model to the unpasteurized and pasteurized mixed nectars cashew apple, mango, and acerola

\begin{tabular}{|c|c|c|c|c|c|c|c|c|}
\hline \multirow{2}{*}{ Nectar } & \multicolumn{2}{|c|}{$\mathrm{K}\left(\mathrm{Pa} . \mathrm{s}^{\mathrm{n}}\right)$} & \multicolumn{2}{|c|}{$\mathrm{n}$} & \multicolumn{2}{|c|}{$\mathrm{R}^{2}$} & \multicolumn{2}{|c|}{ QME } \\
\hline & $\mathrm{N}$ & $\mathrm{P}$ & $\mathrm{N}$ & $\mathrm{P}$ & $\mathrm{N}$ & $\mathrm{P}$ & $\mathrm{N}$ & $\mathrm{P}$ \\
\hline 1 & $0.032 \pm 0.002$ & $0.0922 \pm 0.0029$ & $0.702 \pm 0.009$ & $0.6083 \pm 0.0054$ & 0.997 & 0.9988 & 0.000 & 0.0006 \\
\hline 2 & $0.076 \pm 0.004$ & $0.1246 \pm 0.003$ & $611 \pm 0.009$ & $0.5731 \pm 0.0048$ & 0.997 & 0.99 & 0.001 & 0.0006 \\
\hline 3 & $0.040 \pm 0.005$ & $0.0815 \pm 0.0028$ & $.684 \pm 0.005$ & $0.6160 \pm 0.0058$ & 0.987 & 0.9987 & 0.004 & 0.0006 \\
\hline 4 & $0.8097 \pm 0.489$ & $0.2939 \pm 0.0445$ & $0.229 \pm 0.101$ & $0.4485 \pm 0.0261$ & 0.942 & 0.9478 & 0.405 & 0.0277 \\
\hline 5 & $0.0354 \pm 0.001$ & $0.1025 \pm 0.0153$ & $0.693 \pm 0.006$ & $0.5789 \pm 0.0256$ & 0.999 & 0.9655 & 0.000 & 0.0155 \\
\hline 6 & $0.0757 \pm 0.005$ & $0.1019 \pm 0.0038$ & $0.612 \pm 0.012$ & $0.5926 \pm 0.0067$ & 0.994 & 0.9979 & 0.002 & 0.0011 \\
\hline 7 & $0.1277 \pm 0.017$ & $0.2191 \pm 0.0351$ & $0.509 \pm 0.023$ & $0.4725 \pm 0.0279$ & 0.964 & 0.9395 & 0.008 & 0.0290 \\
\hline 8 & $0.2408 \pm 0.055$ & $0.1961 \pm 0.0178$ & $0.381 \pm 0.039$ & $0.5017 \pm 0.0157$ & 0.806 & 0.9850 & 0.029 & 0.0079 \\
\hline 9 & $0.0887 \pm 0.005$ & $0.1231 \pm 0.0077$ & $0.587 \pm 0.009$ & $0.5639 \pm 0.0108$ & 0.996 & 0.9945 & 0.001 & 0.0029 \\
\hline 10 & $0.0987 \pm 0.009$ & $0.0869 \pm 0.0054$ & $0.536 \pm 0.015$ & $0.5971 \pm 0.0106$ & 0.988 & 0.9953 & 0.003 & 0.0019 \\
\hline
\end{tabular}

$\mathrm{N}$ : unpasteurized; P: pasteurized; K: consistency index $\left(\mathrm{Pa} . \mathrm{s}^{\mathrm{n}}\right)$; n: flow behaviour index

The non-Newtonian behaviour and pseudoplastic character of fruit pulps have been observed by other studies. CHIN and co-workers (2009) found that grapefruit juice could be classified as a non-Newtonian fluid, showing a pseudoplastic behaviour, similar to that described by BRANCO and GASPARETto (2003), who analysed the rheological behaviour of ternary mixtures of mango pulp, orange, and carrot juice. VANDRESSEN (2007) studied the effect of heat treatment on the rheological properties of unpasteurized and pasteurized carrot juice. The model of Ostwald de Waele was fitted to the results, observing Newtonian behaviour for unpasteurized and pseudoplastic behaviour for pasteurized juices. The latter result was similar to the results obtained in this study.

For the production of fruit nectars, differences in rheological behaviour is likely to occur as the physicochemical composition of fruit changes with species; however, within the same species but different varieties, studies have showed that the rheological behaviour of nectars is not significantly affected. DAK and co-workers $(2006 ; 2007)$ studied the rheological behaviour of different mango juice varieties, "Totapuri" and "Kesar", and pseudoplastic behaviour was observed for both varieties.

The nectars that were subjected to heat treatment had a higher $(\mathrm{P}<0.05)$ consistency index $(\mathrm{K})$ compared to those not submitted to heat treatment, except for formulations 4,8 , and 10. The flow behaviour index $(\mathrm{n})$ of nectars presented higher $(\mathrm{P}<0.05)$ values for unpasteurized samples, except for nectars 4, 8, and 10. MACEIRAS and co-workers (2007) evaluated the effect of cooking pastes, and found that the flow behaviour index (n) decreased when samples were subjected to heat treatment, similarly to the results observed for most formulations in this study. For flow behaviour index (n), the closer to unity the greater the tendency of fluids to behave like Newtonian fluid (RAmOs \& IBARZ, 1998).

Apparent viscosity was significantly different among formulations. Concentration and denaturation of pulp constituents have likely occurred during heat treatment for the formulations tested; and consequently these formulations were more viscous $(\mathrm{P}<0.05)$ than the formulations not submitted to heat treatment. The results of apparent viscosity for the unpasteurized and pasteurized formulations were well represented by the linear model and by 
the cubic model, respectively (Table 3). The quadratic model did not show a good fit to the experimental data for any of the rheological parameters studied and it was not used. The coefficients of linear and cubic equations for the representation of consistency index, flow behaviour index, and apparent viscosity, as well as their standard errors are listed in Tables 4 and 5.

Table 3. Summary of analysis of variance (ANOVA) for apparent viscosity, consistency, and flow behaviour index

\begin{tabular}{|c|c|c|c|c|c|c|c|}
\hline \multirow{3}{*}{ Source of variation } & \multirow{3}{*}{ DF } & \multicolumn{6}{|c|}{ Mean square } \\
\hline & & \multicolumn{2}{|c|}{$\mathrm{K}\left(\mathrm{Pa} . \mathrm{s}^{\mathrm{n}}\right)$} & \multicolumn{2}{|c|}{$\mathrm{n}$} & \multicolumn{2}{|c|}{$\eta_{a}$ (Pa.s) } \\
\hline & & $\mathrm{N}$ & $\mathrm{P}$ & $\mathrm{N}$ & $\mathrm{P}$ & $\mathrm{N}$ & $\mathrm{P}$ \\
\hline Linear model & 6 & $0.0303^{\mathrm{ns}}$ & $0.0173 *$ & $0.0115^{\mathrm{ns}}$ & $0.0089^{\mathrm{ns}}$ & $0.0014 *$ & $0.00007^{*}$ \\
\hline Lack of fit & 3 & $0.0234^{\mathrm{ns}}$ & $0.0145^{*}$ & $0.0303^{\mathrm{ns}}$ & $0.0194^{\mathrm{ns}}$ & $0.0021^{\mathrm{ns}}$ & $0.00003^{*}$ \\
\hline Quadratic model & 5 & $0.0363^{\mathrm{ns}}$ & $0.0238^{*}$ & $0.0308^{*}$ & $0.0201^{\mathrm{ns}}$ & $0.0008^{\mathrm{ns}}$ & $0.00006^{*}$ \\
\hline Lack of fit & 4 & $0.0176^{\mathrm{ns}}$ & $0.0043 *$ & $0.0202 *$ & $0.0133^{\mathrm{ns}}$ & $0.0001^{\mathrm{ns}}$ & $0.000005^{\mathrm{ns}}$ \\
\hline Cubic model & 2 & $0.0673^{\mathrm{ns}}$ & $0.0199 *$ & $0.0283 *$ & $0.0191^{\mathrm{ns}}$ & $0.0007^{\mathrm{ns}}$ & $0.00006^{*}$ \\
\hline Lack of fit & 7 & $0.0167^{\mathrm{ns}}$ & $0.0057^{*}$ & $0.0218 *$ & $0.0129^{\mathrm{ns}}$ & $0.0002^{\mathrm{ns}}$ & $0.000004^{\mathrm{ns}}$ \\
\hline
\end{tabular}

N: Unpasteurized; P: pasteurized; DF: Degree of freedom; * Significant at 5\% of probability level; ns: not significant at $5 \%$ of probability; $\eta_{\mathrm{a}}$ : apparent viscosity; K: consistency index $\left(\mathrm{Pa} . \mathrm{s}^{\mathrm{n}}\right)$; n: flow behaviour index

Table 4. Coefficients and standard errors of the adjusted linear model for the rheological parameters

\begin{tabular}{|c|c|c|c|c|c|c|c|c|c|}
\hline & \multicolumn{3}{|c|}{$\mathrm{K}$} & \multicolumn{3}{|c|}{$\mathrm{n}$} & \multicolumn{3}{|c|}{$\eta_{\mathrm{a}}$} \\
\hline & $\mathrm{x}_{1}$ & $\mathrm{x}_{2}$ & $\mathrm{x}_{3}$ & $x_{1}^{\prime}$ & $\mathrm{x}_{2}^{\prime}$ & $\mathrm{x}_{3}$ & $\mathrm{x}_{1}$ & $\mathrm{x}_{2}{ }_{2}$ & $\mathrm{x}_{3}$ \\
\hline \multicolumn{10}{|l|}{ Pasteurized } \\
\hline coefficients & $0.181^{*}$ & $0.176^{*}$ & $0.071^{*}$ & $0.552 *$ & $0.487 *$ & $0.5730 *$ & $0.019^{*}$ & $0.018^{*}$ & $0.012 *$ \\
\hline Standard errors & $0.029 *$ & $0.029 *$ & $0.029^{*}$ & $0.051^{*}$ & $0.051 *$ & $0.0509 *$ & $0.002 *$ & $0.002 *$ & $0.002 *$ \\
\hline \multicolumn{10}{|l|}{ Unpasteurized } \\
\hline coefficients & $0.099^{\mathrm{ns}}$ & $0.265^{*}$ & $0.026^{*}$ & $0.574 *$ & $0.538^{*}$ & $0.637^{*}$ & $0.007^{\mathrm{ns}}$ & $0.037^{\mathrm{ns}}$ & $0.005^{\text {ns }}$ \\
\hline Standard errors & $0.061^{\mathrm{ns}}$ & $0.061^{*}$ & $0.061^{\mathrm{ns}}$ & $0.045^{*}$ & $0.045^{*}$ & $0.045^{*}$ & $0.008^{*}$ & $0.008^{\mathrm{ns}}$ & $0.008^{\text {ns }}$ \\
\hline
\end{tabular}

$\mathrm{x}_{1}{ }_{1}$ : Cashew apple; $\mathrm{x}_{2}$ : mango; $\mathrm{x}_{3}{ }_{3}$ : acerola. * Significant at $5 \%$ of probability level; ns: not significant at $5 \%$ of probability; $\eta_{\mathrm{a}}$ : apparent viscosity; K: consistency index $\left(\mathrm{Pa} . \mathrm{s}^{\mathrm{n}}\right)$; $\mathrm{n}$ : flow behaviour index

The consistency index increased $(\mathrm{P}<0.05)$ with the increase of mass fraction of mango and cashew apple. The opposite was observed for the flow behaviour index, which increased $(\mathrm{P}<0.05)$ with the increase of mass fraction of acerola (linear model) and mango pulp (cubic model), indicating a reduction of the pseudoplastic behaviour of the mixture. Formulation seven and four showed the highest $(\mathrm{P}<0.05)$ values of consistency index for the unpasteurized and pasteurized mixed nectars, respectively (Table 2). The amount of each pulp present in the formulations should be taken into account, for example formulation eight had higher content of cashew apple pulp and formulation four had the highest amounts of cashew apple and mango pulp. Cashew apple and mango pulps have significantly more fibre and higher soluble 
Table 5. Coefficients and standard errors of the adjusted cubic model for the rheological parameters

\begin{tabular}{|c|c|c|c|c|c|c|c|}
\hline \multirow{2}{*}{ Coefficients } & & \multicolumn{2}{|c|}{$\mathrm{K}$} & \multicolumn{2}{|c|}{$\mathrm{n}$} & \multicolumn{2}{|c|}{$\eta_{\mathrm{a}}$} \\
\hline & & $\mathrm{N}$ & $\mathrm{P}$ & $\mathrm{N}$ & $\mathrm{P}$ & $\mathrm{N}$ & $P$ \\
\hline \multirow[t]{2}{*}{$\mathrm{x}_{1}^{\prime}$} & Coefficients & $0.051^{\mathrm{ns}}$ & $0.099 *$ & $0.672 *$ & $0.591 *$ & $0.009^{\mathrm{ns}}$ & $0.016^{*}$ \\
\hline & Standard errors & $0.083^{\text {ns }}$ & $0.024 *$ & $0.047 *$ & $0.063^{*}$ & $0.011^{\mathrm{ns}}$ & $0.002 *$ \\
\hline \multirow[t]{2}{*}{$\mathrm{x}_{2}{ }_{2}$} & Coefficients & $0.2730^{*}$ & $0.109 *$ & $0.639 *$ & $0.594 *$ & $0.048^{*}$ & $0.017 *$ \\
\hline & Standard errors & $0.083^{\mathrm{ns}}$ & $0.024 *$ & $0.047 *$ & $0.063^{*}$ & $0.011^{*}$ & $0.002 *$ \\
\hline \multirow[t]{2}{*}{$x_{3}^{\prime}$} & Coefficients & $0.063^{\mathrm{ns}}$ & $0.079 *$ & $0.663^{*}$ & $0.628 *$ & $0.011^{\mathrm{ns}}$ & $0.001 *$ \\
\hline & Standard errors & $0.083^{\mathrm{ns}}$ & $0.024 *$ & $0.047 *$ & $0.063^{*}$ & $0.011^{\mathrm{ns}}$ & $0.002 *$ \\
\hline \multirow[t]{2}{*}{$x_{1}^{\prime} x_{2}^{\prime}$} & Coefficients & $0.334^{\mathrm{ns}}$ & $0.757^{*}$ & $-0.740 *$ & $-0.580^{\mathrm{ns}}$ & $-0.043^{\mathrm{ns}}$ & $0.027^{*}$ \\
\hline & Standard errors & $0.415^{\mathrm{ns}}$ & $0.119^{*}$ & $0.234^{\mathrm{ns}}$ & $0.315^{\mathrm{ns}}$ & $0.0571^{\mathrm{ns}}$ & $0.009^{*}$ \\
\hline \multirow[t]{2}{*}{$x^{\prime}{ }_{1} x_{3}^{\prime}$} & Coefficients & $0.071^{\mathrm{ns}}$ & $0.089^{\mathrm{ns}}$ & $-0.054^{\mathrm{ns}}$ & $-0.117^{\mathrm{ns}}$ & $0.0046^{\mathrm{ns}}$ & $0.001^{\mathrm{ns}}$ \\
\hline & Standard errors & $0.415^{\mathrm{ns}}$ & $0.119^{\text {ns }}$ & $0.235^{\text {ns }}$ & $0.315^{\mathrm{ns}}$ & $0.0571^{\mathrm{ns}}$ & $0.009^{\text {ns }}$ \\
\hline \multirow[t]{2}{*}{$x_{2}^{\prime} x_{3}^{\prime}$} & Coefficients & $-0.435^{\mathrm{ns}}$ & $-0.039^{\mathrm{ns}}$ & $-0.081^{\mathrm{ns}}$ & $-0.726^{*}$ & $-0.074^{\mathrm{ns}}$ & $-0.019 *$ \\
\hline & Standard errors & $0.415^{\text {ns }}$ & $0.119^{\text {ns }}$ & $0.235^{\mathrm{ns}}$ & $0.315^{*}$ & $0.057^{\mathrm{ns}}$ & $0.009 *$ \\
\hline \multirow[t]{2}{*}{$x^{\prime} x_{1}^{\prime}{ }_{2}^{\prime} x_{3}^{\prime}$} & Coefficients & $0.312^{\mathrm{ns}}$ & $-0.275^{\mathrm{ns}}$ & $-2.309^{\mathrm{ns}}$ & $2.207^{\mathrm{ns}}$ & $0.039^{\mathrm{ns}}$ & $0.052^{\mathrm{ns}}$ \\
\hline & Standard errors & $2.737^{\mathrm{ns}}$ & $0.788^{\mathrm{ns}}$ & $1.546^{\mathrm{ns}}$ & $2.078^{\mathrm{ns}}$ & $0.377^{\mathrm{ns}}$ & $0.057^{\mathrm{ns}}$ \\
\hline
\end{tabular}

$\mathrm{x}_{1}$ : cashew apple; $\mathrm{x}_{2}$ : mango; $\mathrm{x}_{3}$ : acerola. $\mathrm{N}$ : unpasteurized; P: pasteurized; $\eta_{\mathrm{a}}$ : apparent viscosity; $\mathrm{K}$ : consistency index (Pa.s); n: flow behaviour index; * Significant at 5\% of probability level; ns: not significant at 5\% of probability

solids than the other pulps, which may have contributed to this behaviour. BRANCO and GASPARETTO (2005) evaluated the rheological behaviour of mixtures of carrot and orange juices, and mango pulps that were unpasteurized; and observed an increase in the rheological parameter values with an increase in the mass fraction of mango pulp in their mixture, similar to this study.

In general, an increase in mass fraction of cashew apple and mango pulps showed an increase $(\mathrm{P}<0.05)$ in apparent viscosity and in the consistency index of pasteurized and unpasteurized formulations (Fig. 1 and Table 6). This behaviour was not observed for the flow behaviour index. For unpasteurized formulations, a decrease $(\mathrm{P}<0.05)$ in flow behaviour index values with an increase in mass fraction of cashew apple and mango pulps was observed. An increase in mass fraction of acerola pulp in the formulation caused a significant reduction of flow behaviour index values.

A significant decrease of shear stress values with shear rate was observed for unpasteurized formulations compared to their respective pasteurized counterparts. This could be explained by analysing the apparent viscosity of each formulation (Table 6 and Fig. 2), where the pasteurized formulations have shown higher $(\mathrm{P}<0.05)$ apparent viscosities values, justifying the higher $(\mathrm{P}<0.05)$ shear stress values when compared to the unpasteurized formulations. 
Table 6. Apparent viscosity ( $\mathrm{\eta}$ ) of mixed nectars of cashew apple, mango, and acerola

\begin{tabular}{ccc}
\hline \multirow{2}{*}{ Nectar } & \multicolumn{2}{c}{$\eta_{\mathrm{a}}(\mathrm{Pa} . \mathrm{s})$} \\
\cline { 2 - 3 } & $\mathrm{N}$ & $\mathrm{P}$ \\
\hline 1 & 0.0081 & 0.0152 \\
2 & 0.0127 & 0.0175 \\
3 & 0.0093 & 0.0139 \\
4 & 0.0232 & 0.0232 \\
5 & 0.0086 & 0.0147 \\
6 & 0.0127 & 0.0156 \\
7 & 0.0134 & 0.0193 \\
8 & 0.0139 & 0.0198 \\
9 & 0.0132 & 0.0165 \\
10 & 0.0117 & 0.0136 \\
\hline
\end{tabular}

N: unpasteurized; P: pasteurized.

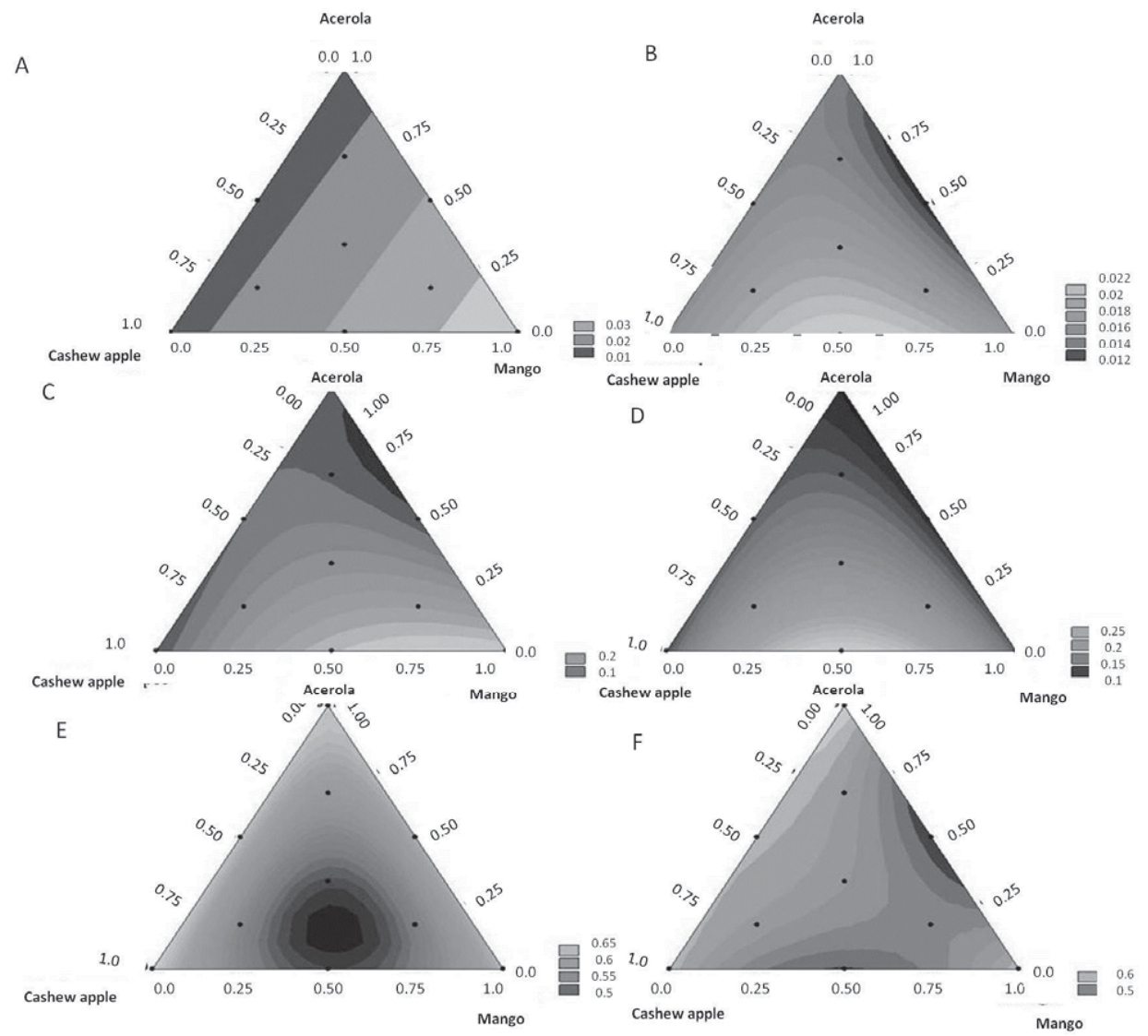

Fig. 1. Rheological parameters contour curves: A: Linear model for apparent viscosity of unpasteurized nectars

$\left(\mathrm{R}^{2}=0.601\right)$; B: cubic model for apparent viscosity of pasteurized nectars $\left(\mathrm{R}^{2}=0.217\right)$; : cubic model for consistency index of unpasteurized nectars $\left(\mathrm{R}^{2}=0.266\right)$; D: Cubic model for consistency index pasteurized nectars $\left(\mathrm{R}^{2}=0.742\right)$; E: Cubic model for flow behaviour index of unpasteurized nectars $\left(\mathrm{R}^{2}=0.514\right)$; F: Cubic model for the flow behaviour index of pasteurized nectars $\left(\mathrm{R}^{2}=0.284\right)$ 

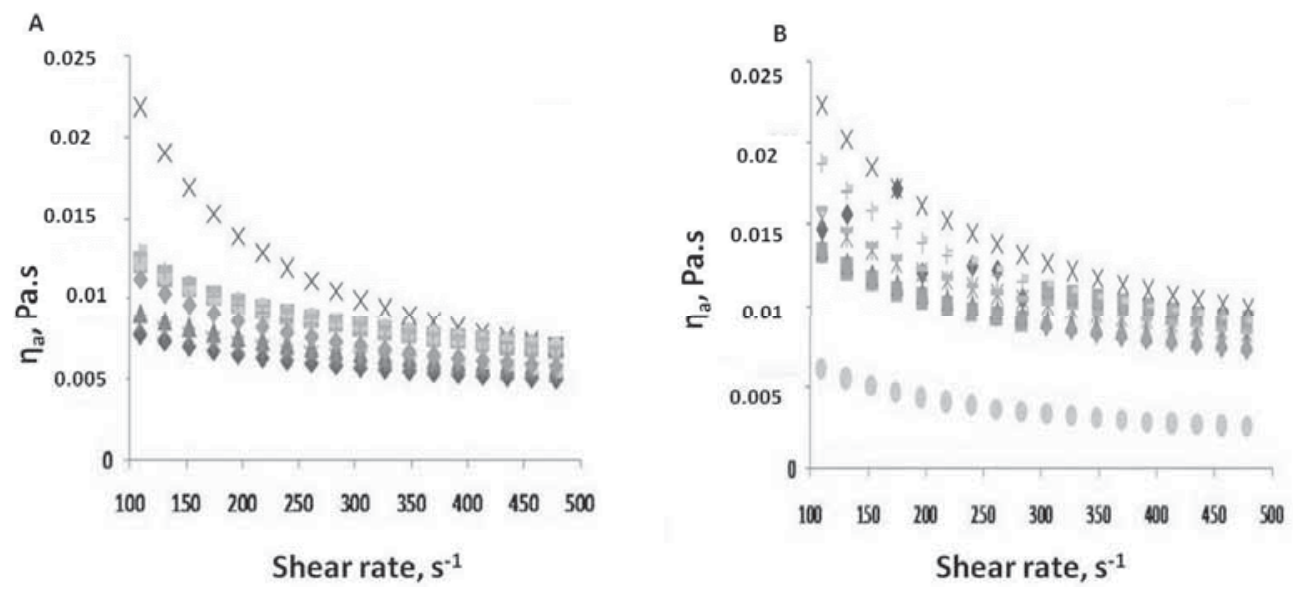

Fig. 2. Relationship between apparent viscosity $\left(\eta_{\mathrm{a}}\right)$ and shear stress of mixed nectars of cashew apple, mango, and acerola. A: unpasteurized nectars; B: pasteurized nectars

४: $1 ; \square: 2 ; \triangle: 3 ; \times: 4 ; *: 5 ;$ O: $6 ;+: 7 ; \mathbf{\square}: 8 ;-: 9 ; \diamond: 10$

\section{Conclusions}

The Ostwald de Waele model showed a good fit for all formulations. The heat treatment applied to the mixed nectars of cashew apple, mango, and acerola resulted in higher $(\mathrm{P}<0.05)$ values of the consistency index and apparent viscosity and lower $(\mathrm{P}<0.05)$ values of flow behaviour index. Therefore, the formulations subjected to heat treatment were characterized as non-Newtonian fluids with a pseudoplastic behaviour. Results of apparent viscosity for the unpasteurized formulations were well described by the linear model and for the pasteurized formulations by the cubic model. The increase in mass fraction of cashew apple and mango pulps caused an increase $(\mathrm{P}<0.05)$ in apparent viscosity and consistency index of nectars.

The authors wish to thank the "Coordenação de Aperfeiçoamento Pessoal de Nível Superior - CAPES" and the "Conselho Nacional de Pesquisa para o Desenvolvimento Científico e Tecnológico - CNPq" for financial support.

\section{References}

Andrade, A.P.S., Oliveira, V.H., Innecco, R. \& Silva, E.O. (2008): Qualidade de cajus-de-mesa obtidos nos sistemas de produção integrada e convencional. (Post-harvest quality of cashew apples from integrated fruit production and conventional cropping systems.) Rev. Bras. Frutic., 30, 176-179.

Bon, J., VÁquiro, H., Benedito, J. \& Telis-Romero, J. (2010): Thermophysical properties of mango pulp (Mangifera indica L. cv. Tommy Atkins). J. Fd Engng, 97, 563-568.

Branco, I.G. \& Gasparetto, C.A. (2003): Comportamento reológico de suco de laranja concentrado congelado. (Rheological behaviour of frozen concentrated orange juice.) Revi. Bras. Produtos Agroindustriais, 5, 173178.

Branco, I.G\&Gasparetto, C.A. (2005): Comportamento reológico de misturas de polpa de manga utilizando modelo de Casson. (Rheological behaviour of mixtures of mango pulp with orange and carrot juices according to the Casson model.) Braz. J. Fd Technol., 8, 183-189.

CAswell, H. (2009): The role of fruit juice in the diet: an overview. Nutr. Bull., 34, 273-288. 
Chin, N.L., Chan, S.M., Yusof, Y.A., Chuan, T.G.\& Talib, R.A. (2009): Modeling of rheological behavior of pummelo juice concentrates, using master-curve. J. Fd Engng, 93, 134-140.

Dak, M., Verma, R.C.\& Sharma, G.P. (2006): Flow characteristics of juice of “Totapuri” mangoes. J. Fd Engng, 76, 557-561.

DAK, M., VERMA, R.C.\& JAAFFREY, S.N.A. (2007): Effect of temperature and concentration on rheological properties of "Kesar" mango juice. J. Fd Engng, 80, 1011-1015.

Ferreira, R.Q.\&AvacA, L.A. (2008): Determinação eletroquímica da capacidade antioxidante de sucos de frutas industrializados usando o CRAC Assay. (Electrochemical determination of the antioxidant capacity of industrialized fruits juices using the CRAC assay.) Quim. Nova, 31, 2169-2173.

Freitas, C.A.S., MaiA, G.A., Costa, J.M.C.\&Sousa, P.H.M. (2006): Acerola: produção, composição, aspectos nutricionais e produtos. (Acerola: production, composition, nutritional aspects, and products.) Rev. Bras. Agrociência, 12, 395-400.

Hoffmann-Ribani, R., Huber, L.S. \& Rodriguez-Amaya, D.B. (2009): Flavonols in fresh and processed Brazilian fruits. J. Fd Comp. Anal., 22, 263-268.

Lima, A.S., Maia, G.A., Sousa, P.H.M., Silva, F.G.V. \& Figueiredo, E.A.T. (2008): Desenvolvimento de bebida mista a base de água de coco e suco de acerola. (Development of a blended beverage consisting of coconut water and acerola juice.) Ciênc. Tecnol. Alimentos, 28, 683-690.

Maceiras, R., Álvarez, E. \& Cancela, M.A. (2007): Rheological properties of fruit purees: Effect of cooking. $J$. Fd Engng, 80, 763-769.

Melo, E.A., Maciel, M.I.S., Lima, V.L.A.G.\&AraúJo, C.R. (2008): Teor de fenólicos totais e capacidade antioxidante de polpas congeladas de frutas. (Levels of total phenolics and antioxidant capacity of frozen fruit pulps.) Alimentos Nutrição, 19, 67-72.

Mezadri, T., Villaño, D., Fernández-Pachón, M.S., García-Parilla, M.C.\& Troncoso, A.M. (2008): Antioxidants compounds and antioxidant activity in acerola (Malpighia emarginata, D.C.) fruits and derivatives. $J$. Fd Compos. Anal., 21, 282-290.

Ramadan-Hassanien, M.F. (2008): Total antioxidant potential of juices, beverages and hot drinks consumed in Egypt screened by DPPH in vitro assay. Grasas Aceit., 59, 254-259.

Ramos, A.M.\& Ibarz, A. (1998): Density of juice and fruit puree as a function of soluble solids and temperature. J. Fd Engng, 35, 57-63.

Ribeiro, S.M.R., Queiroz, J.H., Queiroz, M.E.L.R., Campos, F.M.\&Sant’ana, H.M.P. (2007): Antioxidant in Mango (Mangifera indica L.) pulp. Pl. Fds Human Nutr., 62, 13-17.

VANDRESSEN, S. (2007): Caracterização físico-química e comportamento reológico de sucos de cenoura e laranja e suas misturas. (Physical chemical characterization and rheological behaviour of carrot and orange juices and their blends.) Universidade Federal de Santa Catarina, Brasil, 134 pages

VAsques, C.T. (2003): Reologia do suco de goiaba: Efeito da diluição e do tamanho de partícula. (Rheology of guava juice: Effect of dilution and particle size.) Universidade Federal de Santa Catarina, Brasil, 66 pages

ZEPKA, L.Q.\& Mercadante, A.Z. (2009): Degradation compounds of carotenoids formed during heating of a simulated cashew apple juice. Fd Chem., 117, 28-34. 